(c) American Dairy Science Association, 2003.

\title{
Assessment of the Opsonic Activity of Purified Bovine sIgA Following Intramammary Immunization of Cows with Staphylococcus aureus
}

\author{
M. B. Barrio, P. Rainard, F. B. Gilbert, and B. Poutrel \\ Equipe Mammites \\ Laboratoire de la Pathologie Infectieuse et Immunologie \\ INRA, 37380 Nouzilly, France
}

\begin{abstract}
The phagocytosis of Staphylococcus aureus by bovine polymorphonuclear neutrophils (PMN) requires the presence of antibodies. Among the major isotypes of bovine antibodies, $\mathrm{IgG}_{2}$ and IgM are considered opsonic for bovine PMN. However, the role of purified bovine secretory IgA (sIgA) as an opsonin has not been assessed. In the present study, $\operatorname{IgG}_{2}$ were obtained from serum and $\mathrm{sIgA}, \operatorname{IgG}_{1}$, and IgM were purified from the colostrums of three cows intramammarily immunized with heat-killed Staphylococcus aureus. The Ig preparations were assayed for specific antibodies, and the opsonic capacity of every isotype was investigated. Despite the presence of antibodies, we observed no distinct chemiluminescence response of PMN stimulated with

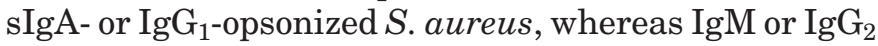
bound to bacteria induced a marked chemiluminescence response. Moreover, the counting of internalized bacteria per PMN after phagocytosis revealed a low uptake of $S$. aureus opsonized with $\operatorname{sigA}$ or $\operatorname{IgG}_{1}$, in contrast to IgM or $\mathrm{IgG}_{2}$, which triggered efficient ingestion of bacteria. Priming of neutrophils by TNF- $\alpha$, IFN$\gamma$, or C5 ${ }^{\text {desArg }}$ did not promote an oxidative burst or uptake of SIgA-opsonized $S$. aureus to a greater extent than with $\mathrm{IgG}_{1}$-opsonized bacteria. Furthermore, analysis of uningested bacteria by flow cytometry after incubation with PMN showed a preferential uptake of IgMopsonized S. aureus by PMN and only few sIgA-positive stained bacteria were PMN-associated. These experiments indicate that $\mathrm{SIgA}$, like $\operatorname{IgG}_{1}$ and unlike IgM or $\mathrm{IgG}_{2}$, could not be considered as a major opsonin for phagocytosis of $S$. aureus by bovine blood PMN.
\end{abstract}

(Key words: sIgA, opsonization, neutrophil, Staphylococcus aureus)

Abbreviation key: $\mathbf{C L}=$ chemiluminescence, $\mathbf{O D}=$ optical density, $\mathbf{P M N}$ = polymorphonuclear neutrophil, $\mathbf{S C}=$ secretory component, $\mathbf{s I g A}=$ secretory IgA.

Received December 20, 2002.

Accepted April 27, 2003.

Corresponding author: P. Rainard; e-mail: rainard@tours.inra.fr.

\section{INTRODUCTION}

Staphylococcus aureus is one of the major causes of bovine mammary gland infection. The ability of neutrophils to phagocytose the invading bacteria is a key component of the innate mammary immunity (Paape et al., 2000). Optimal phagocytosis generally requires the presence of complement components and specific antibodies that recognize the bacterium through Fab regions and bind the $\mathrm{Fc}$ receptors on the phagocyte (Howard et al., 1980). In cattle, the main antibody isotypes are $\operatorname{IgA}, \operatorname{IgM}, \operatorname{IgG}_{1}$, and $\operatorname{IgG}_{2}$ (Butler, 1998).

Even though $\mathrm{IgG}_{1}$ is the predominant isotype in lacteal secretions, particularly in colostrum, this isotype is not opsonic for bovine neutrophils (McGuire et al., 1979; Howard et al., 1980). Bovine $\mathrm{IgG}_{2}$ is considered as cytophilic for neutrophils and a potent opsonin for phagocytosis (Watson, 1976; Lascelles, 1979). Guidry and co-workers demonstrated that $\mathrm{IgG}_{2}$ and IgM are opsonic for bovine polymorphonuclear neutrophils (PMN) and able to enhance phagocytosis of S. aureus. They also observed that $\mathrm{IgG}_{1}$ inhibits the activity of both isotypes (Guidry et al., 1993). Another study concluded that Escherichia coli and S. aureus were more readily phagocytosed by bovine PMN when they were opsonized with $\operatorname{IgM}$ than with $\mathrm{IgG}_{2}$ (Williams and Hill, 1982).

We currently recognize four classes of receptors for IgG $(\mathrm{Fc} \gamma \mathrm{R})$ on bovine immune cells (Bianchi et al., 1996). Neutrophils primarily express the $\mathrm{IgG}_{2}$ binding $\mathrm{FcR}$, while monocytes/macrophages express $\mathrm{FcR}(\mathrm{s})$ that bind both IgG isotypes. Although unidentified, there is some evidence that bovine milk PMN bear receptors for IgM (Grewal et al., 1978). A study by Zhang and coworkers revealed that bovine granulocytes and monocytes bind human IgA, indicating the presence of an IgA-binding FcR (Zhang et al., 1995). However, little is known about the opsonic activity of bovine IgA, and their implication for phagocytosis of mastitis pathogens. A significant correlation between IgA concentration in milk and phagocytosis of $S$. aureus by bovine PMN has been shown (Guidry et al., 1980a, 1980b; 
Miller et al., 1988). Nevertheless, no direct evidence exists with respect to the opsonic activity of bovine secretory IgA ( $\mathbf{I g A}$ ). As far as the human $\operatorname{sIgA}$ is concerned, divergent conclusions have been drawn regarding their opsonic activity (Wilson, 1972; Zipursky et al., 1973; Gorter et al., 1987; Stewart and Kerr, 1990). Here, we purified bovine sIgA from colostrum in an attempt to elucidate whether this Ig isotype could, by binding to bacteria, promote the phagocytosis of $S$. aureus by bovine neutrophils. As a comparison, we also purified bovine $\operatorname{IgG}_{1}, \mathrm{IgG}_{2}$, and IgM since their opsonic activity has extensively been reported.

\section{MATERIALS AND METHODS}

\section{Bacterial Strains and Preparation of $S$. aureus for Immunization}

Staphylococcus aureus strains 776.10 and 159.06 belonging to our collection and used for immunization and in vitro experiments were initially isolated from cows with mastitis and thereafter lyophilized. These strains express type 8 or 5 capsular polysaccharide, respectively, as determined by ELISA for type 8 (Poutrel et al., 1988) or by flow cytometry for type 5 (Poutrel et al., 1997). Each strain was checked for purity on sheep blood esculin agar plates. For immunization, bacteria were grown in different culture conditions in order to allow expression of a large variety of surface antigens. Three consecutive 24 -h cultures at $37^{\circ} \mathrm{C}$ of strain 776.10 were performed in Brain Heart Infusion (BHI, Difco, Becton Dickinson, Le Pont de claix, France) supplemented with $0.25 \%$ (wt/vol) glucose for slime production (Ammendolia et al., 1999). Furthermore, this strain was grown either until the logarithmic or the stationary phase at $37^{\circ} \mathrm{C}$ in BHI. Both strains were incubated on sheep blood esculin agar plates at $37^{\circ} \mathrm{C}$ for $3 \mathrm{~d}$ and plated immediately on Modified-110 agar plates for two consecutive 24-h cultures to promote capsule expression. After growth, bacteria were harvested, centrifuged $\left(2000 \times g, 15 \mathrm{~min}, 4^{\circ} \mathrm{C}\right)$, and washed once with PBS, $\mathrm{pH}$ 7. The resuspended pellets in pyrogen-free saline solution of $S$. aureus were heat-killed $\left(88^{\circ} \mathrm{C}\right.$ for $\left.15 \mathrm{~min}\right)$ and viability of bacteria was checked by plating out on blood agar plates. Before measuring of optical density (OD), the bacteria were sonicated (150W ultrasonic disintegrator; MSE, Crawley, UK) to disrupt bacterial clumps (power setting 5 , tune 4). Bacterial suspensions grown in different culture conditions were adjusted to correspond to $2.5 \times 10^{9} \mathrm{cfu} / \mathrm{ml}$ in pyrogen-free isotonic saline solution and stored separately at $-20^{\circ} \mathrm{C}$ until use. Before immunization, suspensions of the two $S$. aureus strains were thawed, vortexed to assure a uniform suspension of the organisms, and pooled (the dose for immunization of each quarter was of $10^{10} \mathrm{cfu}$ ).

\section{Animals, Immunization Procedure, and Sampling}

Three Holstein-Friesian cows before their third lactation and belonging to our experimental herd were selected on the basis of the absence of mastitis episodes in their clinical history and absence of IMI at time of immunization. On the first day of drying off, the right front and rear quarters of each cow were infused with the pooled heat-killed $S$. aureus suspensions through the teat canal and by massaging the quarter to disperse the organisms. A booster dose was given $30 \mathrm{~d}$ later, during the dry period. The teat ends were systematically sanitized before infusion with $70 \%$ alcohol. Three cows in the beginning of their third lactation, for which no placebo was administered, were chosen as control group. Colostral samples were collected for purification of Ig isotypes and for determination of specific antibodies to $S$. aureus. Milk samples were also collected $5 \mathrm{~d}$ after calving from immunized quarters for use as a standard reference for $\operatorname{IgG}_{1}$ and IgA antibodies in the ELISA. Contralateral quarters served as noninfused controls. Bovine serum was obtained from jugular blood collected about $3 \mathrm{~d}$ before calving and was stored at $-20^{\circ} \mathrm{C}$ until use for purification of $\mathrm{IgG}_{2}$.

Normal bovine serum was prepared by pooling serum from 10 clinically healthy cows of our experimental herd. The complement system in serum was inactivated by heating at $56^{\circ} \mathrm{C}$ for $30 \mathrm{~min}$. Aliquots were stored at $-70^{\circ} \mathrm{C}$ and thawed only once just before use.

\section{Purification of Ig}

$\operatorname{IgA}, \mathrm{IgG}_{1}$, and $\operatorname{IgM}$ of each cow were separated from the colostrums of immunized quarters and $\mathrm{IgG}_{2}$ from serum. As $\mathrm{IgG}_{2}$ antibodies against $S$. aureus were detected only in the serum from one immunized cow, this serum was used for the $\operatorname{IgG}_{2}$ purification. After precipitation of colostral wheys with ammonium sulfate at $33 \%$ saturation, the resolubilized pellet was dialyzed against $0.01 M$ PBS, $\mathrm{pH} 7$. The Ig solution was then applied onto an equilibrated DEAE-Trisacryl M (LKB, IBF, Pointet Girard, France) column. Elution was done either with a $0.04 M$ PBS pH 7 in order to obtain an Ig fraction, which contained mainly $\operatorname{IgG}_{1}$ and IgA, or with a $0.06 \mathrm{M}$ PBS $\mathrm{pH} 7$ to obtain an IgM rich fraction. The Ig solutions were concentrated with polyethylene glycol (PEG 20,000, Prolabo, Merck Eurolab): cellulose tubings (Cellu Sep, 6000-8000, Membrane Filtration Products, Inc., TX) containing the eluted fractions were put on solid polyethylene glycol at $4^{\circ} \mathrm{C}$. When the Ig solutions were concentrated (below $10 \mathrm{ml}$ ), they were dialyzed against $0.15 M$ PBS $\mathrm{pH}$ 7. The different isotypes in every eluted fraction were separated by sizeexclusion chromatography through a series of three 16$\times 900$-mm columns of Sephacryl S-300 High Resolution 
(Amersham Pharmacia Biotech AB, Uppsala, Sweden) equilibrated with $0.15 M$ PBS pH 7 containing $0.15 M$ $\mathrm{NaCl}$ and $0.01 \% \mathrm{NaN}_{3}$ (Bouvet et al., 1990). A protein amount of about 100 to $150 \mathrm{mg}$ in less than $10 \mathrm{ml}$ was applied to the series of three columns. The outflow was controlled by a peristaltic pump (Econo Pump, Bio-Rad, $\mathrm{CA}$ ) and adjusted to $0.15 \mathrm{ml} / \mathrm{min}$. This chromatographic step lasted $6 \mathrm{~d}$ in order to allow an optimal separation of Ig isotypes. Their distribution was determined by isotype-specific ELISA as described elsewhere (Van Zaane, 1984) except that immunoreagents were the same as for the whole-cell ELISA described in this paper. Peaks corresponding to $\mathrm{IgG}_{1}$ or IgM were concentrated by dialysis against polyethylene glycol and finally dialyzed against $20 \mathrm{~m} M$ PBS $\mathrm{pH} 7$. Purification of the sIgA was further accomplished by fast protein liquid chromatography through a Protein G Sepharose column (HiTrap protein G, Amersham Biosciences) in order to remove residual IgG. The flowthrough fraction corresponding to sIgA was finally dialyzed against 20 $\mathrm{m} M$ PBS $\mathrm{pH} 7$.

For $\mathrm{IgG}_{2}$ purification, the Ig contained in the serum were precipitated with ammonium sulfate at $33 \%$ saturation. The pellet was solubilized, dialyzed against 0.01 $M$ PBS, $\mathrm{pH}$ 8.3, and applied on a DEAE-Trisacryl M column equilibrated in the same buffer. The $\mathrm{IgG}_{2}$ were isolated in the "fall-through" fraction as the buffer $\mathrm{pH}$ did not allow their binding to the ion exchanger. A slight shoulder manifested at the descending limb of the curve, which indicated some heterogeneity. We therefore pooled only the first fractions.

All isotype solutions were stored on ice until use. Concentrations were determined assuming the absorbance at $280 \mathrm{~nm}$ of $1 \mathrm{mg} / \mathrm{ml}$ solution to be 1.37 (Duncan et al., 1972).

\section{Electrophoretic and Western Blotting Analysis of Ig Isotypes}

The purity of Ig isotype preparations was estimated by SDS-polyacrylamide gel (7\%, wt/vol) electrophoresis under reducing conditions (Laemmli, 1970). The electrophoresis was pursued after the dye front reached the bottom of the gel in order to let the light chains migrate out of the gel. Proteins were visualized by staining with silver nitrate (Oakley et al., 1980). Additionally, Ig were detected by Western blotting. Proteins were transferred to a nitrocellulose membrane $(0.45$ $\mu \mathrm{m})$ (Sartorius AG, Göttingen, Germany) according to Towbin et al. (1979). Following electroblotting, membranes were blocked for $1 \mathrm{~h}$ at room temperature with PBS supplemented with $0.5 \%$ (wt/vol) gelatin (PBSG0.5 ). The sequence of incubation steps, separated by three washes with PBS supplemented with $0.1 \%$ (vol/ vol) Tween-20 (PBS-T) was as follows for the western blotting of IgA: 1) a 1/100 dilution in PBS plus $0.1 \%$ (wt/vol) gelatin and $0.1 \%$ (vol/vol) Tween-20 (PBSTG0.1 ) of a mouse IgG mAb anti-bovine/ovine IgA (Serotec, Oxford, UK) during $2 \mathrm{~h}$ at room temperature, 2) a 1/ 1000 dilution in PBSTG-0.1 of a peroxidase-conjugated goat antibody anti-mouse IgG (mAb heavy- and lightchain specific; Jackson Immunoresearch Inc.) during 1 $\mathrm{h}$ at room temperature. A unique incubation step was needed for the western blotting of IgM or IgG with a 1/ 2000 dilution in PBSTG- 0.1 of a peroxidase-conjugated sheep IgG anti-bovine IgM (Serotec) or a 1/1500 dilution in PBSTG-0.1 of a peroxidase-conjugated mouse IgG $\mathrm{mAb}$ anti-bovine IgG (mAb heavy- and light-chain specific; Jackson Immunoresearch Inc., West Grove, PA) for $1 \mathrm{~h}$ at room temperature. After washing the blots twice with PBS-T and a third time with deionized water, the peroxidase-conjugated antibodies were detected by a 1/10 dilution of 4-chloronaphthol/3,3'-diaminobenzidine, tetrahydrochloride solution in stable peroxide substrate buffer (HRP substrates for blotting, PIERCE, Rockford, IL).

Homogeneity of Ig preparations was demonstrated by SDS-PAGE analysis in the absence of reducing agents on a 3 to $6 \%$ gradient polyacrylamide gel. A polyester film (Gel-Fix for PAG, Serva, Germany) was incorporated during the casting of this gel in order to bind the polyacrylamide gel as well as maintaining its integrity during the subsequent silver nitrate staining procedure. Purified bovine IgM isotype (Sigma Chemicals, St. Louis, MO) was incorporated as a control.

For detection of the secretory component $(\mathbf{S C})$ in the IgA preparation, an anti-sIgA immunoblot was performed after separating the SC, heavy and light chains from colostral purified SIgA on a 7\% polyacrylamide gel under reducing conditions. Proteins were transferred to a nitrocellulose membrane and the sequence of incubation steps were as described above, except that the membrane was first probed with a 1/50 dilution in PBSTG-0.1 of a rabbit anti-bovine sIgA serum (Nordic Immunological Laboratories, Tilburg, The Netherlands) for $2 \mathrm{~h}$ at room temperature and then incubated with a 1/5000 dilution in PBSG-0.1 of peroxydase-conjugated goat anti-rabbit IgG $(\mathrm{H}+\mathrm{L})$ antibodies (Jackson Immunoresearch Inc.) for $1 \mathrm{~h}$ at room temperature.

\section{PMN Isolation}

Blood samples, obtained from clinically healthy cows more than 1 mo in lactation and not involved in the immunization protocol, were aseptically drawn from the coccygeal (tail) vein by venipuncture into sterile tubes containing EDTA (Vacutainer). Bovine PMN were isolated from blood according to the method of 
Carlson and Kaneko (1973) and adjusted to $10^{7}$ cells/ $\mathrm{ml}$ in RPMI 1640 medium (RPMI, GIBCO Life Technologies, Paisley, Scotland, UK) containing $\mathrm{Ca}^{2+}$ and $\mathrm{Mg}^{2+}$ and supplemented with $0.1 \%$ (wt/vol) BSA and $25 \mathrm{mM}$ HEPES buffer (Sigma) (RPMI-AH). Immediately after isolation, the viability of PMN was determined by trypan blue dye exclusion. On average, viability was higher than $99 \%$.

\section{Determination of Specific Antibodies to $S$. aureus by Whole-cell ELISA}

A human S. aureus strain that does not express protein A (strain Wood 46) was used to coat the plates. Flat-bottomed 96-well microtiter plates (Maxisorp Immunoplates; Nunc, Roskilde, Denmark) were prepared by overnight incubation at $37^{\circ} \mathrm{C}$ with $100 \mu \mathrm{l}$ of a suspension (OD at $600 \mathrm{~nm}$ of 0.1 ) of heat-killed (at $60^{\circ} \mathrm{C}$ for $30 \mathrm{~min}$ ) S. aureus Wood 46 in $50 \mathrm{mM} \mathrm{pH} 9.6$ carbonatebicarbonate buffer. The plates were washed once and unsaturated binding sites were blocked with PBSG-0.5. The sequence of incubation steps, separated by three washes with PBS-T, was as follows for detection of IgA, $\mathrm{IgG}_{2}$, or $\mathrm{IgG}_{1}$ antibodies: 1 ) a 1/500 colostrum dilution or $50 \mu \mathrm{g} / \mathrm{ml}$ of each Ig-preparation diluted in PBSG-0.1, 2) a $1 / 750$ dilution in PBSG-0.1 of a mouse $\operatorname{IgG}_{1} \mathrm{mAb}$ anti-bovine/ovine IgA (Serotec), a 1/100 dilution in PBSG- 0.1 of a mouse IgG $_{1}$ mAb anti-bovine IgG $_{2}$ (Serotec), a 1/5000 dilution in PBSG-0.1 of a mouse IgG $\mathrm{mAb}$ anti-bovine IgG 1 (gift from D. Van Zaane, CDI, Lelystad, The Netherlands) and 3) a 1/10,000 dilution in PBSG-0.1 of a peroxidase-conjugated goat antibody anti-mouse IgG (mAb heavy- and light-chain specific; Jackson Immunoresearch Inc.). For the detection of IgM antibodies, a unique incubation step was needed after the incubation with colostrums or Ig-preparations: a 1/ 10,000 dilution in PBSG-0.1 of a peroxidase-conjugated sheep IgG anti-bovine IgM (Serotec). Dilutions of immune reagents were incubated for $1 \mathrm{~h}$ at $37^{\circ} \mathrm{C}$ and a $52 \mathrm{~m} M$ solution of 2,2'-azido-di-(3-ethylbenzthiazolinesulfonate) in $0.1 M$ citrate buffer ( $\mathrm{pH} 4.2$ ) with $0.075 \%$ hydrogen peroxide was added for revelation. After 30 min at room temperature, the $\mathrm{OD}$ at $415 \mathrm{~nm}\left(\mathrm{OD}_{415}\right)$ was read with a Titertek Multiscan spectrophotometer (Flow Laboratories). Titers of antibodies in colostrum samples are given in units. The six milk samples of immunized quarters collected $5 \mathrm{~d}$ after calving were pooled and used as a reference for $\operatorname{IgG}_{1}$ and IgA antibodies with an arbitrary value of 500 units. A pooled serum from 10 clinically healthy cows was used as a reference for IgM and $\mathrm{IgG}_{2}$ with an arbitrary value of 400 units. Six dilutions of this reference milk or serum were included in each plate and a computer program was used to extrapolate the absorbance value of colostrums under test to units. The use of these arbitrary units allowed us to quantify the relative variations of Ab reactivity following immunization.

\section{Phagocytosis Assays}

Luminol-dependent chemiluminescence (CL) assay. The limited quantities of SIgA, obtained after purification, forced us to restrict to one the number of $S$. aureus strains used for the phagocytosis assays. Therefore, we chose strain 776.10 and one of the culture conditions used for the vaccine, in order to induce expression of the same surface antigens against which antibodies were supposed to have been elicited. Staphylococcus aureus strain 776.10 was grown in BHI overnight at $37^{\circ} \mathrm{C}$. Bacteria were opsonized by incubating $0.05 \mathrm{ml}$ of the bacterial suspension (adjusted in RPMIAH to a concentration of $10^{9} \mathrm{cfu} / \mathrm{ml}$ ) with $0.45 \mathrm{ml}$ of increasing concentrations of Ig isotypes $(6.25,25,100$, or $400 \mu \mathrm{g} / \mathrm{ml}$ for IgM and IgG $_{2}$ isotypes; $100,200,400$, or $800 \mu \mathrm{g} / \mathrm{ml}$ for $\mathrm{IgG}_{1}$ and $25,50,100$, and $200 \mu \mathrm{g} / \mathrm{ml}$ for $\operatorname{IgA}$ ). Incubation was allowed for $30 \mathrm{~min}$ at $37^{\circ} \mathrm{C}$. The bacteria were then washed once with PBS (800 $\times g, 5 \mathrm{~min}, 4^{\circ} \mathrm{C}$ ) and resuspended in RPMI-AH at a concentration of $10^{8} \mathrm{cfu} / \mathrm{ml}$. Phagocytic mixture contained $0.25 \mathrm{ml}$ of the bacterial suspension mixed with $0.1 \mathrm{ml}$ of PMN suspension $\left(10^{7}\right.$ cells $\left./ \mathrm{ml}\right)$ into RPMI-AH, $0.1 \mathrm{ml}$ of a $10^{-4} M$ solution of Luminol (Sigma) and $0.01 \mathrm{ml}$ (10 $\mathrm{n} M$ final concentration) of purified bovine C5 ${ }^{\text {desArg }}$ (Rainard et al., 1998).

In experiments involving priming of cells, neutrophils were incubated with $0.5 \mu \mathrm{g} / \mathrm{ml}$ (or $1000 \mathrm{U} / \mathrm{ml}$ ) of $\mathrm{r}$ BoIFN- $\gamma$ (Genentech Inc., San Francisco, CA) for $2 \mathrm{~h}$ at room temperature (Sordillo and Babiuk, 1991) or with $10 \mathrm{ng} / \mathrm{ml}$ (Rainard et al., 2000) of r-BoTNF- $\alpha$ (Genentech Inc., San Francisco, CA) for 30 min at $37^{\circ} \mathrm{C}$ with rocking. Priming of cells was performed in 4-ml polypropylene vials that had been coated with $0.1 \%$ (wt/ vol) BSA $\left(37^{\circ} \mathrm{C}\right.$ for $\left.1 \mathrm{~h}\right)$ to minimize adherence of cells to the tube wall (Rainard et al., 2000). As mentioned above, priming with $10 \mathrm{nM}$ of $\mathrm{C}^{\mathrm{a}} \mathrm{a}^{\mathrm{desArg}}$ was performed by its addition to the phagocytic mixture. Control tubes contained cells for which no stimulating agent was added. For these experiments, concentrations of 200 $\mu \mathrm{g} / \mathrm{ml}$ for IgA or IgM and $800 \mu \mathrm{g} / \mathrm{ml}$ for $\mathrm{IgG}_{1}$ were used for opsonization of bacteria.

The CL was measured at $38^{\circ} \mathrm{C}$ in a LKB-Wallac 1251 luminometer (Pharmacia LKB Biotechnology, Uppsala, Sweden) at 4-min intervals for $40 \mathrm{~min}$. In each run, cuvettes contained PMN with either unopsonized bacteria or PMN without bacteria (control). At the end of the run, the area under the curve $(\mathrm{mV} \times \mathrm{s})$ over the 40 -min period was recorded. All samples were run in duplicate. The results are median from three independent IgA, 
IgM, or IgG $\mathrm{G}_{1}$ preparations and one representative experiment with $\mathrm{IgG}_{2}$.

Microscopic examination of ingestion. Phagocytic mixtures at the end of the CL assay were used to study ingestion of bacteria by PMN. Lysostaphin $(1 \mu \mathrm{g} /$ $\mathrm{ml}$ final concentration, Sigma) was added and incubation was performed for $10 \mathrm{~min}$ at $37^{\circ} \mathrm{C}$ in order to lyse extracellular bound bacteria and any bacterial clumps not associated with PMN. The use of lysostaphin under our experimental conditions permitted to bring to zero the OD at $600 \mathrm{~nm}$ of a suspension of $10^{9} \mathrm{cfu} / \mathrm{ml}$ of $S$. aureus (strain 776.10). Cytocentrifuge (Shandon Southern, Pittsburgh, PA) smears were prepared immediately after incubation and stained with May-GrünwaldGiemsa reagents. At least $100 \mathrm{PMN}$ were scored microscopically (magnification, $\times 1000$ ) for internalized bacteria. Results were expressed as the mean number of ingested bacteria per PMN.

Analysis of uningested bacteria by flow cytometry after phagocytosis. Staphylococcus aureus strain 776.10 (about $10^{8} \mathrm{cfu}$ in $0.05 \mathrm{ml}$ of RPMI-AH) were opsonized for $30 \mathrm{~min}$ at $20^{\circ} \mathrm{C}$ with $0.45 \mathrm{ml}$ of the IgA $(200 \mu \mathrm{g} / \mathrm{ml})$ or IgM $(6.25$ or $200 \mu \mathrm{g} / \mathrm{ml})$ preparations diluted in RPMI-AH. A control tube (unopsonized bacteria) received $0.45 \mathrm{ml}$ of RPMI-AH. Bacteria were then washed once with filtered PBS $(0.2-\mu \mathrm{m}$ pore size $)$ containing $1 \mathrm{mg} / \mathrm{ml}$ of BSA (low endotoxin grade; Sigma) (PBS-A). Bacteria were centrifuged $(8000 \times g, 5 \mathrm{~min}$, $4^{\circ} \mathrm{C}$ ), resuspended in RPMI-AH and sonicated for $10 \mathrm{~s}$ to disrupt clumps. To $0.25 \mathrm{ml}$ of bacterial suspension, $0.25 \mathrm{ml}$ of PMN suspension $\left(10^{7}\right.$ cells $\left./ \mathrm{ml}\right)$ and $0.010 \mathrm{ml}$ of $\mathrm{C}^{\mathrm{a}} \mathrm{a}^{\mathrm{des} A r g}$ (10 $\mathrm{n} M$ final concentration) were added. Phagocytosis was allowed to proceed for $30 \mathrm{~min}$ at $37^{\circ} \mathrm{C}$ with end-over-end rotation. Control tubes contained only bacteria in RPMI-AH without PMN. These tubes were incubated in parallel and were treated in the same manner as experimental samples.

Once the phagocytosis incubation was finished, the PMN were pelleted at low centrifugal force $(200 \times g$ for $4 \mathrm{~min})$. The supernatant was transferred to Eppendorf tubes and sonicated $8 \mathrm{~s}$ for homogeneity of bacteria suspension. Then $0.1 \mathrm{ml}$ of supernatant was incubated $30 \mathrm{~min}$ at $4^{\circ} \mathrm{C}$ with $0.05 \mathrm{ml}$ (1/100 final dilution) of a FITC-conjugated $\mathrm{F}\left(\mathrm{ab}^{\prime}\right)_{2}$ fragment rabbit anti-bovine IgG (mAb heavy- and light-chain specific; Jackson Immunoresearch Laboratories). Bacteria were washed once with filtered PBS-A and resuspended in $1 \mathrm{ml}$ of filtered deionized water. Analysis was carried out on a flow cytometer (FACScan; Becton Dickinson Immunocytochemistry Systems, Mountain View, CA) connected to the LYSIS II software program developed by the manufacturer. Small debris and remaining bacterial aggregates were electronically excluded on the basis of light scatter signals. The settings of the cytometer were adjusted for optimum reading and kept constant throughout the study. The features of 10,000 bacteria were quantified and compared with background values obtained for unopsonized bacteria, which were also incubated with the FITC-conjugated antibody.

In addition to the percentages of stained, unstained bacteria and the mean fluorescence intensity, the relative concentration of bacteria in each tube was recorded. To achieve this, $5 \mu \mathrm{l}$ of a calibrated suspension of beads of known density (Microsphere standard, Bacteria Counting Kit B-7277, Molecular Probes, Eugene, OR) were added per tube to assess the percentage depletion of PMN-free bacteria from the phagocytic mixture as an indirect measure of phagocytosis.

\section{RESULTS}

\section{Detection of Antibodies to $S$. aureus and Purification of Ig Isotypes}

Staphylococcus aureus Wood 46, a protein A-deficient strain, was used for antibody detection to prevent nonspecific interactions of protein $\mathrm{A}$ with the $\mathrm{Fc}$ region of IgG. Titers of IgA anti-S. aureus antibodies in colostrums from immunized quarters were markedly superior to those in unimmunized quarters. Specific antibodies of the IgA class could not be found in the sera of any immunized cow. Levels of IgM and IgG $_{1}$ antibodies in the immunized glands were almost identical to those in the contralateral glands (Table 1). Increased $\operatorname{IgG}_{1}$ titers in comparison with unimmunized animals were recorded in colostrums in all immunized animals. On the contrary, in immunized animals, antibody titers of the IgM type did not exceed those in unimmunized animals. Antibodies of $\mathrm{IgG}_{2}$ isotype were not found in colostrums and only detected in serum from one immunized cow. No antibodies of the IgA class were detected in the serum of immunized cows (data not shown). Bovine $\operatorname{IgA}, \operatorname{IgG}_{1}$, and $\operatorname{IgM}$ isotypes were prepared from colostrums of the three locally immunized cows. The $\mathrm{IgG}_{2}$ were prepared from the serum of one cow.

Purity of the Ig preparations was tested on a 7\% SDSPAGE and Western blotting analysis. In each Ig isotype preparation, no contaminants were detected with the specific anti-bovine isotype antibodies (Figure 1).

Analysis of the Ig preparations on 3 to $6 \%$ SDS-PAGE gel in the absence of reducing agents confirmed the purity of these Ig preparations and suggested that they were homogeneous (Figure 2). Moreover, IgM prepared from colostrum and from serum (Sigma) presented the same unique band. Diluted colostrum showed two bands, a major one at a position comparable to that of $\mathrm{IgG}_{1}$ and a slight one at a position similar to that of IgM.

The presence of the SC in the IgA preparation was controlled on a 7\% SDS-PAGE gel under reducing condi- 
Table 1. Antibody titers (arbitrary units) in colostrums from immunized and control groups measured by whole-cell ELISA with Staphylococcus aureus (strain Wood 46) immobilized on the plates. A heat-killed suspension of $S$. aureus (strains 776.10 and 159.06) was intramammarily infused twice during the dryingoff period in the right front and rear quarters. ${ }^{1}$

\begin{tabular}{llccc}
\hline Cows & Source of colostrum & IgA & IgM & IgG $_{1}$ \\
\hline Immunized group & I-RF and I-RR quarters & 25,266 & 20,304 & 17,056 \\
& & $(23,302 ; 28,112)$ & $(15,870 ; 24,615)$ & $(13,751 ; 22,606)$ \\
& LF and LR quarters & 8,505 & 16,695 & 16,277 \\
& & $(6,477 ; 10,530)$ & $(9,118 ; 21,425)$ & $(13,386 ; 21,151)$ \\
Control group & RF and RR quarters & 4,201 & 20,712 & 2,771 \\
& & $(3,605 ; 4,981)$ & $(17,971 ; 22,631)$ & $(1,953 ; 3,332)$ \\
& LF and LR quarters & 5,226 & 20,592 & 3,341 \\
& & $(4,126 ; 6,107)$ & $(17,526 ; 22,765)$ & $(2,845 ; 3,661)$ \\
\hline
\end{tabular}

${ }^{1} \mathrm{RF}=$ right front; $\mathrm{RR}=$ right rear; $\mathrm{LF}=$ left front; $\mathrm{LR}$ = left rear; $\mathrm{I}=$ immunized. Values are expressed as median (quartiles) from six quarters.

tions and subsequent western blotting analysis (Figure 3 ). The band pattern of reduced sIgA molecule shows two bands corresponding to heavy chain and $\mathrm{SC}$ as detected by a rabbit anti-bovine sIgA serum (Figure 3). It is worth pointing out that the mAb directed against bovine IgA did not detect the SC (Figure 1).

The occurrence of antibodies to $S$. aureus in each Ig preparation was also detected by ELISA with the use of strain Wood 46 (protein A deficient). Results showed that all of the IgA, IgM, and $\operatorname{IgG}_{1}$ preparations $(n=3)$ and the $\mathrm{IgG}_{2}$ preparation $(n=1)$ gave the positive $\mathrm{OD}$ signals (median and quartiles) of $1.1(1 ; 1.2), 2$ (1.9; $2.1), 0.3(0.3 ; 0.3)$ and $1(1 ; 1)$, respectively, for $S$. aureus $\mathrm{Ab}$ detection at a concentration of $50 \mu \mathrm{g} / \mathrm{ml}$.

\section{Phagocytosis}

To determine whether sIgA was opsonic for the $S$. aureus, a CL assay was used to study the oxidative burst activity of PMN stimulated with preopsonized bacteria with increasing concentrations of sIgA. Because opsonic activity of other Ig isotypes is well documented, control phagocytic mixtures with preopsonized bacteria with increasing concentrations of $\operatorname{IgM}, \operatorname{IgG} \mathrm{G}_{1}$, or $\mathrm{IgG}_{2}$ were also included (Figure 4). Unopsonized bacteria did not stimulate PMN (CL of $11,879 \mathrm{mV} \times \mathrm{s}$ ) compared with control tubes with PMN alone (CL of $5989 \mathrm{mV} \times \mathrm{s}$ ). As expected, opsonization with $\mathrm{IgG}_{1}$ for 30 min elicited, in spite of the high concentrations used, only a slight CL response, which contrasted with the remarkable increasing CL response obtained with IgM or $\operatorname{IgG}_{2}$ as opsonins. It is worth noting that sIgA, like $\mathrm{IgG}_{1}$, was a poor inducer of CL response (Figure 4).

We also sought to investigate whether different stimuli for PMN could modify the CL response observed for sIgA-opsonized S. aureus. Priming of PMN with rBoTNF- $\alpha$ or r-BoIFN- $\gamma$ did not increase the CL response or uptake of sIgA-opsonized $S$. aureus as compared to $\mathrm{IgG}_{1}$-opsonized $S$. aureus (Figure 5).
Taken together, these results showed a good relationship between opsonization with IgM or $\operatorname{IgG}_{2}$ and oxidative burst of PMN during phagocytosis of $S$. aureus and a low CL response with IgA or $\operatorname{IgG}_{1}$ as opsonins.

Microscopic examination of cytocentrifuged cell preparations indicated that very few bacteria were internalized by PMN unless serum (5\%), IgG 2 , or IgM were used as opsonin source (Table 2).

Flow cytometric studies were conducted with IgM and SIgA to evaluate a putative correlation between the phagocytic pattern observed by optical microscopy and the binding of $S$. aureus specific sIgA and IgM antibodies to live bacteria (strain 776.10). Results demonstrated that $70 \%$ of the bacterial population bound IgM antibodies to their surface (Table 3). This percentage was remarkably reduced after incubation with PMN, indicating a preferential association of these bacteria to PMN after opsonization with IgM (Table 3). The promoting effect of specific IgM antibodies on the phagocytosis of $S$. aureus was also reflected by the reduction (38\%) of the bacterial concentration in the supernatant after their incubation with PMN. Nevertheless, the proportion of immuno-stained bacteria for sIgA-antibodies bound to $S$. aureus was slightly decreased (from 39 to $31 \%)$ after incubation with PMN. These data indicate that only few sIgA-positive stained bacteria were associated to bovine PMN. Moreover, no reduction in the concentration of sIgA-opsonized bacteria in the supertant after incubation with PMN was observed (Table 3 ).

\section{DISCUSSION}

Local antigenic stimulation of the preparturient mammary gland led to an increase of IgA antibody content only in colostrums from the immunized quarters. These results and the fact that no IgA antibodies were detected in the serum of immunized cows argue in favor of a local production of antibodies of this isotype. In this 


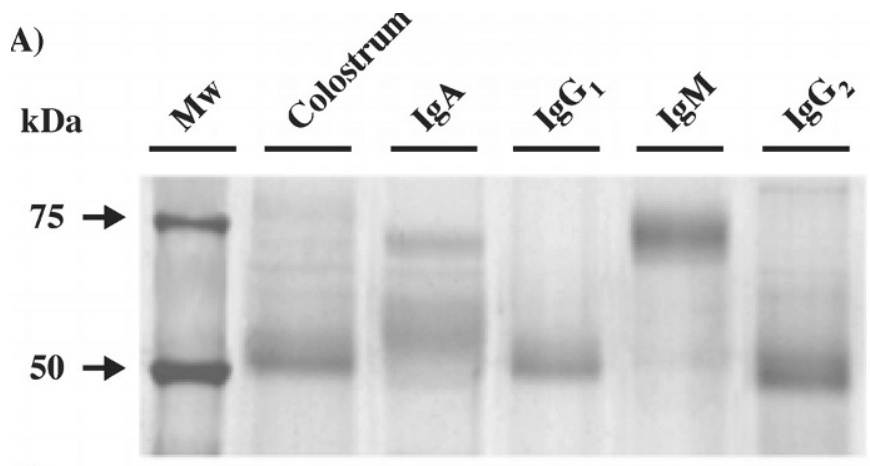

B)

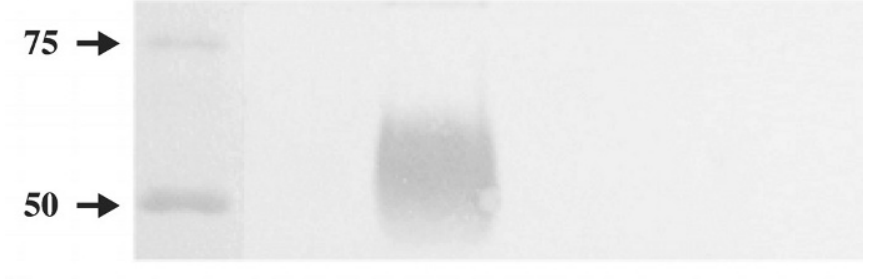

C)

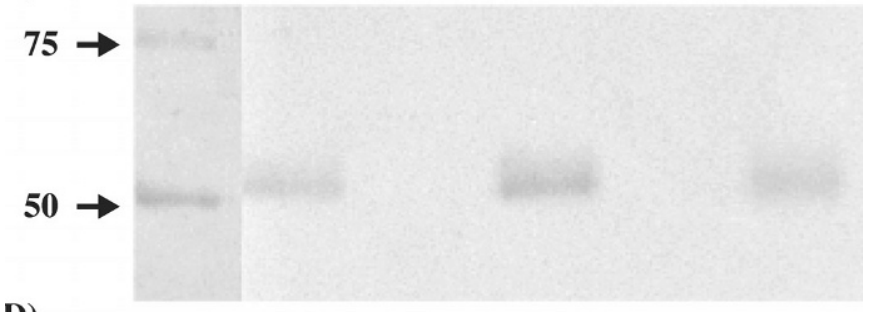

D)

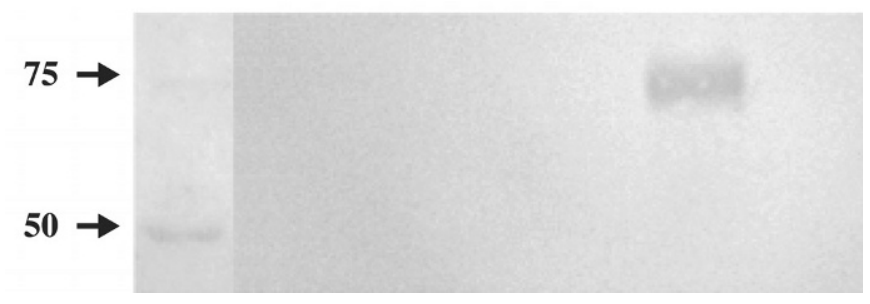

Figure 1. Purity of representative bovine $\operatorname{IgM}, \operatorname{IgA}, \operatorname{IgG}_{1}$, and $\mathrm{IgG}_{2}$ preparations. The Ig proteins were analyzed on a $7 \%$ SDS-PAGE gel under reducing conditions. The electrophoresis was pursued after the dye front reached the bottom of the gel in order to let the light chains migrate out of the gel. Proteins were visualized by staining with silver nitrate (A). Proteins were also subjected to western blotting analysis by using mouse IgG $\mathrm{mAb}$ anti-bovine IgA (B), mouse IgG $\mathrm{mAb}$ anti-bovine $\mathrm{IgG}(\mathrm{H}+\mathrm{L})(\mathrm{C})$, or horseradish peroxidase-conjugated sheep IgG anti-bovine IgM (D) in order to detect the heavy chains.

regard, it has been observed that in cows immunized intramammarily with formalin-killed $S$. aureus, only IgA anticapsular antibodies increased significantly in lacteal secretions (Guidry et al., 1994). Besides, the antibody response of immunized quarters was significantly different from that of contralateral nonimmunized quarters (Guidry et al., 1994). Also, IgA represented a considerable proportion of the immunoglobulin

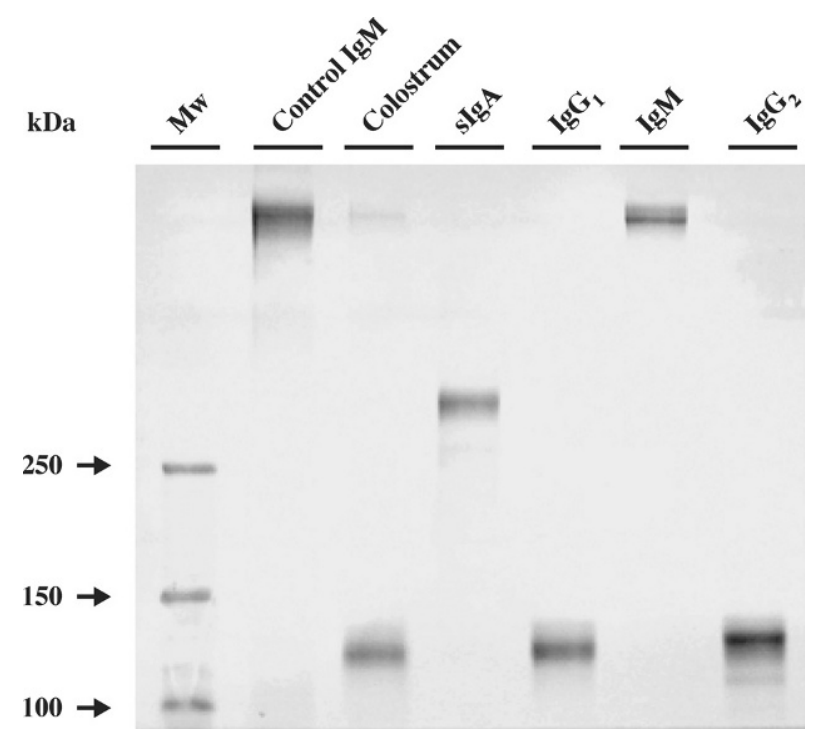

Figure 2. Homogeneity of representative bovine $\operatorname{IgM}, \operatorname{IgA}, \operatorname{IgG}_{1}$, and $\mathrm{IgG}_{2}$ preparations. The Ig proteins were subjected to SDS-PAGE on a 3 to $6 \%$ gradient gel in the absence of reducing agents and stained with silver nitrate. Control IgM lane corresponds to purified bovine IgM (Sigma).

\section{A)}

B)
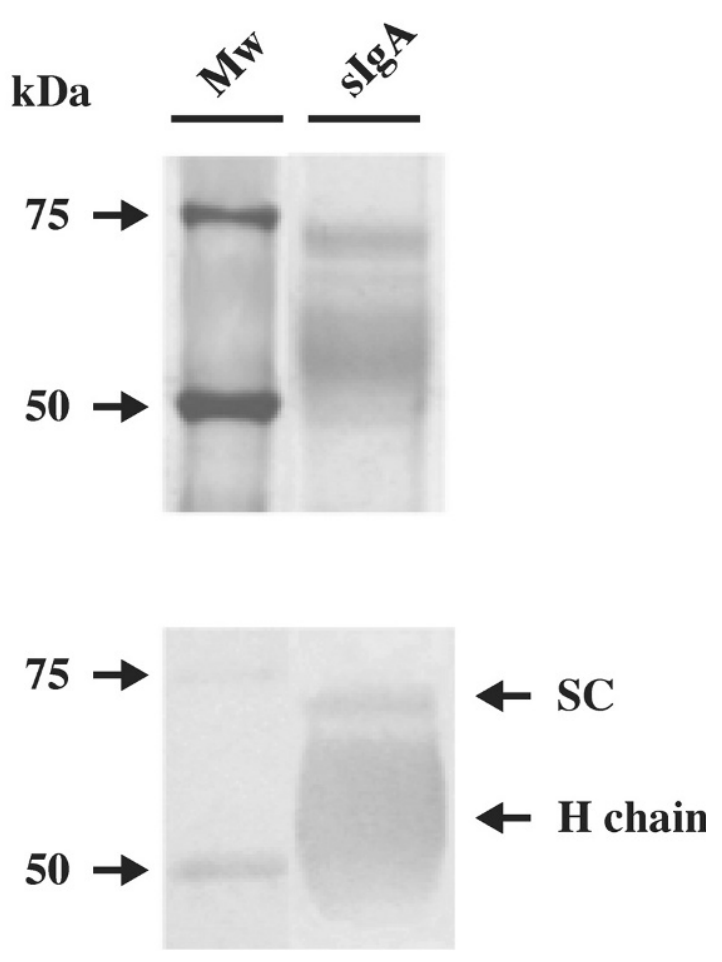

Figure 3. Demonstration of the presence of secretory component (SC) in the IgA preparation purified from colostrum. IgA was subjected to SDS-PAGE on a 7\% gel under reducing conditions and stained with silver nitrate (A). Immunoglobulin A was also subjected to western blotting analysis by using rabbit anti-serum to bovine sIgA. The positions of the $\mathrm{H}$ chain and the SC are indicated. 


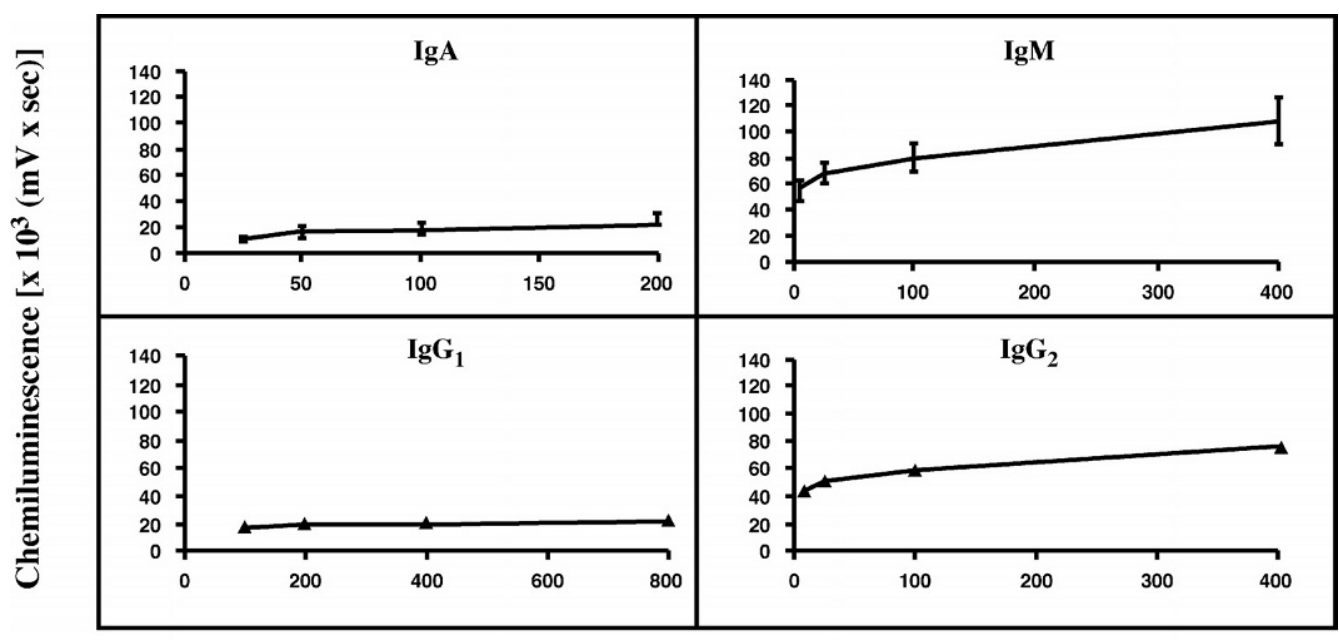

Concentration $(\mu \mathrm{g} / \mathrm{ml})$

Figure 4. Chemiluminescence (CL) responses of bovine polymorphonuclear neutrophils (PMN) induced by phagocytosis of Staphylococcus aureus (strain 776.10). Bacteria were opsonized for $30 \mathrm{~min}$ at $37^{\circ} \mathrm{C}$ with increasing concentrations of Ig isotypes $(6.25,25,100$, or $400 \mu \mathrm{g} /$ $\mathrm{ml}$ for IgM and IgG2 isotypes; 100, 200, 400, or $800 \mu \mathrm{g} / \mathrm{ml}$ for IgG1 and 25, 50, 100, $200 \mu \mathrm{g} / \mathrm{ml}$ for IgA) and thoroughly washed afterwards. PMN, luminol and $10 \mu \mathrm{l}$ of C5adesArg $(10 \mathrm{n} M)$ were then added to the opsonized bacteria to a bacteria/PMN ratio of 25/1. Unopsonized bacteria gave a CL response of $11,879 \mathrm{mV} \times \mathrm{s}$. Data are median (quartiles) from three independent isotype Ig preparations.

in milk after local stimulation in ewes (Lascelles and McDowell, 1970; Watson and Lascelles, 1973). Others reported that IgA antibody was the major Ig isotype in most of the $S$. aureus-infected quarters with subclinical chronic mastitis but not in noninfected ones (Leitner et al., 2000).

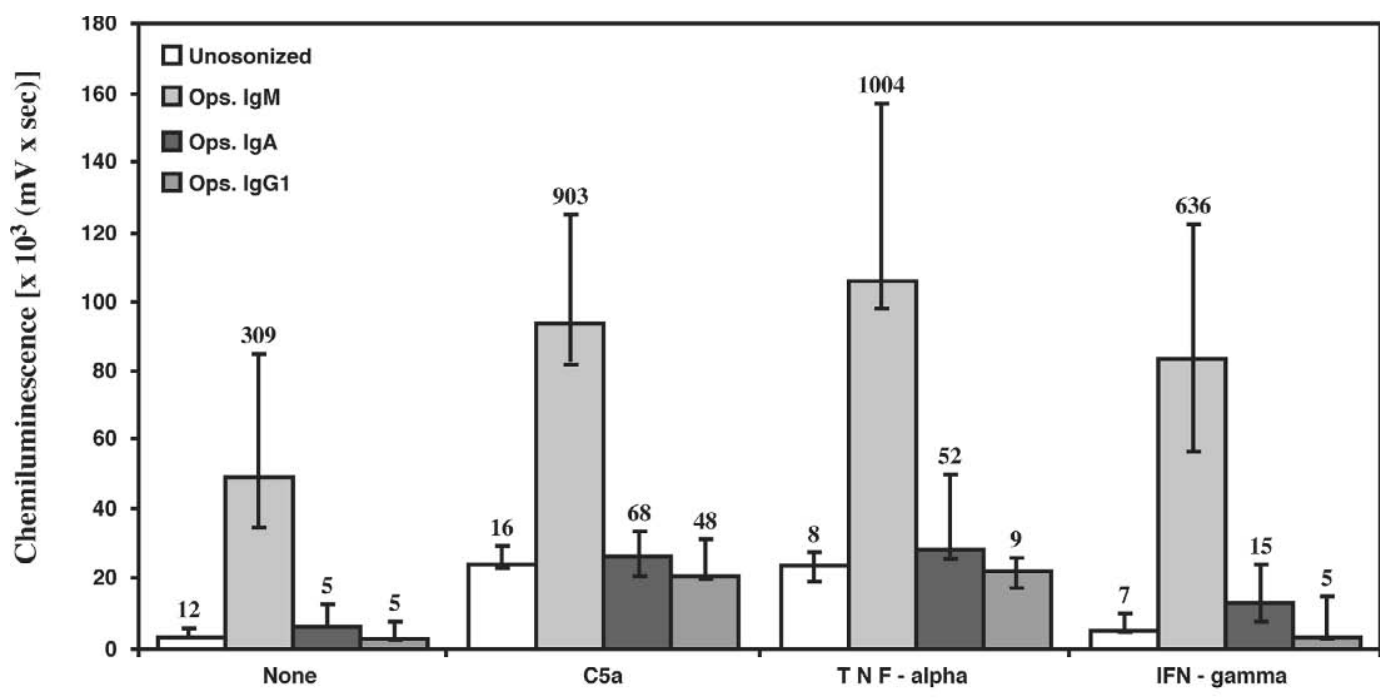

Added PMN activator

Figure 5. Effect of priming on chemiluminescence (CL) responses of bovine polymorphonuclear neutrophils (PMN) induced by phagocytosis of Staphylococcus aureus (strain 776.10). Bacteria were opsonized (Ops.) for $30 \mathrm{~min}$ at $37^{\circ} \mathrm{C}$ with concentrations of $200 \mu \mathrm{g} / \mathrm{ml}$ of IgA or IgM and $800 \mu \mathrm{g} / \mathrm{ml}$ of IgG1 and thoroughly washed afterwards. Neutrophils were preincubated either with $0.5 \mu \mathrm{g} / \mathrm{ml}$ (or $1000 \mathrm{U} / \mathrm{ml}$ ) of r-BoIFN$\gamma$ (IFN-gamma) for $2 \mathrm{~h}$ at room temperature or with $10 \mathrm{ng} / \mathrm{ml}$ of r-BoTNF- $\alpha$ (TNF-alpha) for 30 min at $37^{\circ} \mathrm{C}$. Phagocytic mixtures contained opsonized bacteria, primed PMN (bacteria/PMN ratio of 25/1) and luminol. Priming with $10 \mathrm{nM}$ of C5adesArg (C5a) was performed by its addition to the phagocytic mixture. Control tubes contained cells for which no stimulant was added. Above each column, ingestion (microscopic evaluation after the CL assay) is expressed as the number of internalized $S$. aureus/100 PMN. Data are median (quartiles) from three independent isotype Ig preparations. 
Table 2. Ingestion (microscopic evaluation after the chemiluminescence assay) of opsonized Staphylococcus aureus. ${ }^{1}$

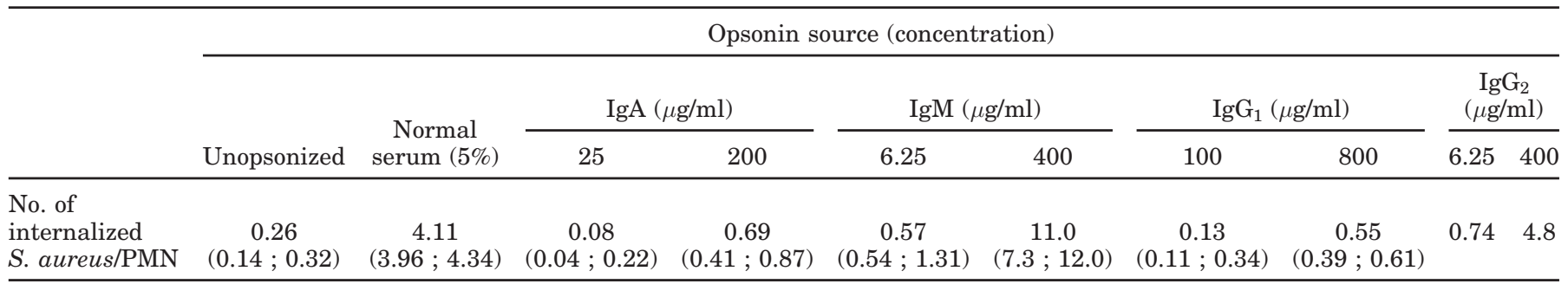

${ }^{1}$ Results are median (quartiles) from three independent isotype Ig preparations except for $\operatorname{IgG}_{2}(n=1)$.

In this work, immunoglobulins of the $\operatorname{IgG}_{1}, \operatorname{IgM}, \operatorname{IgA}$, and $\mathrm{IgG}_{2}$ class were isolated and purity of every Ig preparation was checked by SDS-PAGE and western blotting (Figure 1). Homogeneity of the IgA preparation was demonstrated by SDS-PAGE analysis in the absence of reducing agents and showed a unique band for this isotype (Figure 2). Because SC was present in the same IgA sample (Figure 3) and that all IgA samples showed identical electrophoretic pattern, we assumed that IgA in our preparations corresponded to dimeric sIgA.

Antibody detection was carried out by ELISA, and results showed that all Ig preparations contained $S$. aureus-specific antibodies (see Results section). In addition, binding of sIgA and IgM to S. aureus 776.10 (strain under test) was achieved by indirect immunofluorescence through the flow cytometry study (Table 3 ). Thus, the apparent failure of an isotype to promote neutrophil activity cannot be explained as a lack of specific antibody in the Ig preparations.

We next investigated the opsonic potential of every isotype by studying the interaction during phagocytosis of bovine PMN with Ig isotypes bound to $S$. aureus. This interaction was measured by the CL assay followed by microscopic examination of ingested bacteria per neutrophil (Figure 4 and Table 2, respectively), and the flow cytometry analysis of uningested bacteria after phagocytosis (Table 3). Results showed no apparent dose-dependent CL response of bovine neutrophils to increasing concentrations of $\mathrm{IgG}_{1}$ and uptake of $\mathrm{IgG}_{1^{-}}$ opsonized bacteria did not occur. This finding is attributable to the fact that no binding sites for $\operatorname{IgG}_{1}$ exist on bovine PMN (McGuire et al., 1979; Howard et al., 1980; Guidry et al., 1993). The presence of sIgA during opsonization did not promote ingestion and slightly increased the CL response above the values observed with $\mathrm{IgG}_{1}$. In contrast, neutrophils internalized bacteria opsonized with IgM or $\operatorname{IgG}_{2}$ and showed a trend of enhanced response with increasing doses of these isotypes. These results are in agreement with previously reported data showing that IgM or $\operatorname{IgG}_{2}$ are efficient opsonins for bovine PMN (Lascelles, 1979; Williams and Hill, 1982; Guidry et al., 1993).

Our flow cytometry analysis (Table 3 ) indicated that purified bovine sIgA failed to facilitate $S$. aureus association to or uptake by bovine PMN. Therefore, it was surprising that sIgA from colostrum was not responsible for bacterial opsonization, since a positive statistic

Table 3. Flow cytometry analysis of antibody binding on uningested Staphylococcus aureus after phagocytosis by bovine polymorphonuclear neutrophils (PMN). Bacteria were first opsonized for $30 \mathrm{~min}$ in heated $\left(56^{\circ} \mathrm{C}\right.$ for $\left.30 \mathrm{~min}\right)$ normal bovine serum, in IgM or in IgA preparations. They were subsequently washed and incubated for $30 \mathrm{~min}$ without or with PMN to a bacteria/PMN ratio of $1 / 1$. After differential centrifugation, $S$. aureus in supernatant was stained by indirect immunofluorescence for antibodies to $S$. aureus. Additionally, a suspension of beads (Molecular Probes, Eugene, OR) with known density was used to calculate the concentration of S. aureus in every supernatant. For every opsonization condition, a decrease in concentration of bacteria after incubation with PMN indicates that phagocytosis occurred. ${ }^{1}$

\begin{tabular}{|c|c|c|c|c|c|}
\hline \multirow[b]{3}{*}{ Opsonization } & \multicolumn{4}{|c|}{ Fluorescence of $S$. aureus in supernatant } & \multirow{3}{*}{$\begin{array}{c}\text { Variation }^{3} \text { of } \\
\text { bacteria } \\
\text { concentration }(\%)\end{array}$} \\
\hline & \multicolumn{2}{|c|}{ Incubated without PMN } & \multicolumn{2}{|c|}{ Incubated with PMN } & \\
\hline & $\%$ Stained bacteria & $\mathrm{MFI}^{2}$ & $\%$ Stained bacteria & MFI & \\
\hline Unopsonized & $1.5(1.4 ; 1.6)$ & $7.1(5.5 ; 8.3)$ & $4.6(4.3 ; 5.1)$ & $5.3(4.7 ; 5.4)$ & +8 \\
\hline Serum $10 \%$ & $52(51 ; 60)$ & $23(21 ; 28)$ & $22(21 ; 40)$ & $17(13 ; 23)$ & -45 \\
\hline $\mathrm{IgM}(200 \mu \mathrm{g} / \mathrm{ml})$ & $69(67 ; 70)$ & $23(22 ; 24)$ & $39(35 ; 46)$ & $14(14 ; 14)$ & -38 \\
\hline $\operatorname{IgA}(200 \mu \mathrm{g} / \mathrm{ml})$ & $39(38 ; 40)$ & $13(12 ; 14)$ & $31(30 ; 33)$ & $11(11 ; 11)$ & +17 \\
\hline
\end{tabular}

${ }^{1}$ Results are median (quartiles) from three independent IgM or IgA preparations. Experiments were repeated three times.

${ }^{2}$ Mean fluorescence intensity of stained bacteria.

${ }^{3}$ For every opsonization condition: \% variation of bacteria concentration in supernatant = (concentration of bacteria incubated with PMN $\times 100$ /concentration of bacteria incubated without PMN) -100 . 
correlation has been reported between concentration of bovine IgA in milk samples and phagocytosis of $S$. aureus (Guidry et al., 1980a, 1980b; Miller et al., 1988). Furthermore, when using rabbit anti-serum to bovine IgA, the absorbed wheys of infected quarters with Streptococcus agalactiae lost their opsonic activity (Mackie et al., 1986). Our findings with sIgA are of particular interest as experiments in this report were conducted with purified sIgA. We demonstrated the binding of sIgA to $S$. aureus, but the subsequent association of opsonized bacteria to PMN was not detected (Table 3). Binding of SIgA to PMN was likely since it has been previously shown that a substantial proportion of blood bovine PMN that migrated through micropore filters bound bovine colostral IgA (Berning et al., 1993). In our study, the failure in opsonization by bovine sIgA may be attributable to a low affinity of receptors for this isotype, which could be due to the presence of SC, and $J$ chain that interfered with the recognition of the IgA by $\mathrm{Fc} \alpha \mathrm{R}$ as it has been suggested for human sIgA (Wilson, 1972; van Egmond et al., 2001).

Conflicting reports regarding the opsonic activity of human sIgA are also numerous. Earlier studies suggested that human sIgA binds to human $\mathrm{Fc} \alpha \mathrm{R}$ and acts as an opsonin. They also reported an oxidative burst induced in PMN by serum and SIgA bound to $S$. aureus (Gorter et al., 1987; Stewart and Kerr, 1990). On the contrary, other investigations showed that phagocytosis mediated by human sIgA does not occur (Wilson, 1972; Zipursky et al., 1973). Colostral human neutrophils had low bacterial-killing activity in the presence of sIgA, and authors hypothesized that human sIgAreceptor may mediate noninflammatory effects (Honorio-Franca et al., 2001). Another study demonstrated that surface-adherent $S$. aureus opsonized with milk sIgA were not phagocytized by PMN to any greater extent than unopsonized bacteria (Avery and Gordon, 1991). These discrepancies might be explained by the cellular activation degree suggesting that priming of neutrophils may be required to facilitate IgA-mediated phagocytosis (Weisbart et al., 1988). In the present study, the experiments on phagocytosis were always conducted with stimulated PMN (by the C5 ${ }^{\text {desArg }}$ ) isolated from blood, and the highest concentrations of sIgA that could be tested. These conditions were considered optimal for the assessment of the opsonic capacity of the purified SIgA. When PMN were also primed with r-BoIFN- $\gamma$ or r-BoTNF- $\alpha$ to mimic the conditions encountered by PMN migrating to an inflammatory focus (Rainard et al., 2000), we observed that sIgA were not capable of facilitating ingestion of bacteria (Figure 5). Nevertheless, we cannot neglect the possibility that milk PMN might express Fc $\alpha$ R to a greater extent than primed blood PMN. This, to our best knowledge, has never been documented. On the contrary, the inhibitory effect of fat globules (Paape et al., 1975, 2000) and casein (Dulin et al., 1988; Russell et al., 1977) on the phagocytic activity of milk PMN is well established.

Results presented in this paper show that bovine sIgA are unlikely to mediate protection by acting synergistically with neutrophils. Nevertheless, sIgA may have other functions in controlling the severity of the infection such as immune exclusion, preventing the adherence of bacteria to the epithelium of the mammary gland, or neutralization of toxins produced by microbial pathogens (Mazanec et al., 1993).

In conclusion, this work confirmed the opsonic potential of $\mathrm{IgG}_{2}$ and IgM for the phagocytosis of $S$. aureus and showed that these isotypes were able to induce oxidative burst and ingestion of bacteria by bovine neutrophils. Secretory IgA bound to bacteria but were not capable of triggering effector functions of the PMN and did not act as an opsonin. These results suggest that immunization protocols should aim at promoting synthesis of IgM and $\mathrm{IgG}_{2}$ antibodies in milk for protection of the mammary gland mediated by PMN against $S$. aureus.

\section{ACKNOWLEDGMENTS}

The authors thank J. P. Bouvet (INSERM, Hôpital Broussais, Paris, France) for expert advice regarding the separation of Ig isotypes. We are grateful to J. L. Dacheux and S. Castella (INRA-Tours, Nouzilly, France) for fruitful help in preparing the gradient polyacrylamide gel. We also thank J. Dufrenoy for technical assistance with Ig preparations. The skillful technical assistance of the dairy farm staff in collecting of samples is also appreciated.

\section{REFERENCES}

Ammendolia, M. G., R. Di Rosa, L. Montanaro, C. R. Arciola, and L. Baldassarri. 1999. Slime production and expression of the slimeassociated antigen by staphylococcal clinical isolates. J. Clin. Microbiol. 37:3235-3238.

Avery, V. M., and D. L. Gordon. 1991. Antibacterial properties of breast milk: Requirements for surface phagocytosis and chemiluminescence. Eur. J. Clin. Microbiol. Infect. Dis. 10:1034-1039.

Berning, L. M., M. J. Paape, and R. R. Peters. 1993. Functional variation in endogenous and exogenous immunoglobulin binding to bovine neutrophils relative to parturition. Am. J. Vet. Res. 54:1145-1153.

Bianchi, A., J. E. Butler, J. Hoorfar, C. Howard, and P. Lind. 1996. Workshop summary: Immunoglobulins and Fc receptors. Vet. Immunol. Immunopathol. 54:25-31.

Bouvet, J. P., R. Pires, F. Lunel-Fabiani, B. Crescenzo-Chaigne, P. Maillard, D. Valla, P. Opolon, and J. Pillot. 1990. Protein F. A novel $\mathrm{F}(\mathrm{ab})$-binding factor, present in normal liver, and largely released in the digestive tract during hepatitis. J. Immunol. 145:1176-1180.

Butler, J. E. 1998. Immunoglobulin diversity, B-cell and antibody repertoire development in large farm animals. Rev. Sci. Technol. 17:43-70. 
Carlson, G. P., and J. Kaneko. 1973. Isolation of leukocytes from bovine peripheral blood. Proc. Soc. Exp. Biol. Med. 142:853-856.

Dulin, A. M., M. J. Paape, and S. C. Nickerson. 1988. Comparison of phagocytosis and chemiluminescence by blood and mammary gland neutrophils from multiparous and nulliparous cows. Am. J. Vet. Res. 49:172-177.

Duncan, J. R., B. N. Wilkie, F. Hiestand, and A. J. Winter. 1972. The serum and secretory immunoglobulins of cattle: Characterization and quantitation. J. Immunol. 108:965-976.

Gorter, A., P. S. Hiemstra, P. C. Leijh, M. E. van der Sluys, M. T. van den Barselaar, L. A. van Es, and M. R. Daha. 1987. IgA- and secretory IgA-opsonized $S$. aureus induce a respiratory burst and phagocytosis by polymorphonuclear leucocytes. Immunology 61:303-309.

Grewal, A. S., B. T. Rouse, and L. A. Babiuk. 1978. Characterization of surface receptors on bovine leukocytes. Int. Arch. Allergy. Appl. Immunol. 56:289-300.

Guidry, A. J., C. N. O'Brien, S. P. Oliver, H. H. Dowlen, and L. W. Douglass. 1994. Effect of whole Staphylococcus aureus and mode of immunization on bovine opsonizing antibodies to capsule. J. Dairy Sci. 77:2965-2974.

Guidry, A. J., L. M. Berning, and C. N. Hambleton. 1993. Opsonization of Staphylococcus aureus by bovine immunoglobulin isotypes. J. Dairy Sci. 76:1285-1289.

Guidry, A. J., M. J. Paape, R. E. Pearson, and W. F. Williams. 1980a. Effect of local immunization of the mammary gland on phagocytosis and intracellular kill of Staphylococcus aureus by polymorphonuclear neutrophils. Am. J. Vet. Res. 41:1427-1431.

Guidry, A. J., M. J. Paape, and R. E. Pearson. 1980b. Quarter milk variation in immunoglobulins and ability to support phagocytosis. J. Dairy Sci. 63:611-615.

Honorio-Franca, A. C., P. Launay, M. M. Carneiro-Sampaio, and R. C. Monteiro. 2001. Colostral neutrophils express Fc alpha receptors (CD89) lacking gamma chain association and mediate noninflammatory properties of secretory IgA. J. Leukocyte Biol. 69:289-296.

Howard, C. J., G. Taylor, and J. Brownlie. 1980. Surface receptors for immunoglobulin on bovine polymorphonuclear neutrophils and macrophages. Res. Vet. Sci. 29:128-130.

Laemmli, U. K. 1970. Cleavage of structural proteins during the assembly of the head of bacteriophage T4. Nature 227:680-685.

Lascelles, A. K. 1979. The immune system on the ruminant mammary gland and its role in the control of mastitis. J. Dairy Sci. 62:154-167.

Lascelles, A. K., and G. H. McDowell. 1970. Secretion of IgA in the sheep following local antigenic stimulation. Immunology 19:613-620.

Leitner, G., B. Yadlin, A. Glickman, M. Chaffer, and A. Saran. 2000. Systemic and local immune response of cows to intramammary infection with Staphylococcus aureus. Res. Vet. Sci. 69:181-184.

Mackie, D. P., D. J. Meneely, D. A. Pollock, and E. F. Logan. 1986. The loss of opsonic activity of bovine milk whey following depletion of IgA. Vet. Immunol. Immunopathol. 11:193-198.

Mazanec, M. B., J. G. Nedrud, C. S. Kaetzel, and M. E. Lamm. 1993. A three-tiered view of the role of IgA in mucosal defense. Immunol. Today 14:430-435.

McGuire, T. C., A. J. Musoke, and T. Kurtti. 1979. Functional properties of bovine $\operatorname{IgG}_{1}$ and $\mathrm{IgG}_{2}$ : interaction with complement, macrophages, neutrophils and skin. Immunology 38:249-256.

Miller, R. H., A. J. Guidry, M. J. Paape, A. M. Dulin, and L. A. Fulton. 1988. Relationship between immunoglobulin concentrations in milk and phagocytosis by bovine neutrophils. Am. J. Vet. Res. 49:42-45.
Oakley, B. R., D. R. Kirsch, and N. R. Morris. 1980. A simplified ultrasensitive silver stain for detecting proteins in polyacrylamide gels. Anal. Biochem. 105:361-363.

Paape, M. J., K. Shafer-Weaver, A. V. Capuco, K. Van Oostveldt, and C. Burvenich. 2000. Immune surveillance of mammary tissue by phagocytic cells. Adv. Exp. Med. Biol. 480:259-277.

Paape, M. J., A. J. Guidry, S. T. Kirk, and D. J. Bolt. 1975. Measurement of phagocytosis of 32P-labeled Staphylococcus aureus by bovine leukocytes: Lysostaphin digestion and inhibitory effect of cream. Am. J. Vet. Res. 36:1737-1743.

Poutrel, B., P. Rainard, and P. Sarradin. 1997. Heterogeneity of cellassociated CP5 expression on Staphylococcus aureus strains demonstrated by flow cytometry. Clin. Diagn. Lab. Immunol. 4:275-278.

Poutrel, B., A. Boutonnier, L. Sutra, and J. M. Fournier. 1988. Prevalence of capsular polysaccharide types 5 and 8 among Staphylococcus aureus isolates from cow, goat, and ewe milk. J. Clin. Microbiol. 26:38-40.

Rainard, P., C. Riollet, B. Poutrel, and M. J. Paape. 2000. Phagocytosis and killing of Staphylococcus aureus by bovine neutrophils after priming by tumor necrosis factor-alpha and the des-arginine derivative of C5a. Am. J. Vet. Res. 61:951-959.

Rainard, P., P. Sarradin, M. J. Paape, and B. Poutrel. 1998. Quantification of $\mathrm{C} 5 \mathrm{a} / \mathrm{C} 5 \mathrm{a}(\mathrm{desArg})$ in bovine plasma, serum and milk. Vet. Res. 29:73-88.

Russell, M. W., B. E. Brooker, and B. Reiter. 1977. Electron microscopic observations of the interaction of casein micelles and milk fat globules with bovine polymorphonuclear leucocytes during the phagocytosis of staphylococci in milk. J. Comp. Pathol. 87:43-52.

Sordillo, L. M., and L. A. Babiuk. 1991. Modulation of bovine mammary neutrophil function during the periparturient period following in vitro exposure to recombinant bovine interferon gamma. Vet. Immunol. Immunopathol. 27:393-402.

Stewart, W. W., and M. A. Kerr. 1990. The specificity of the human neutrophil IgA receptor ( $\mathrm{Fc}$ alpha $\mathrm{R}$ ) determined by measurement of chemiluminescence induced by serum or secretory $\operatorname{Ig} \mathrm{A}_{1}$ or $\operatorname{Ig} \mathrm{A}_{2}$. Immunology 71:328-334.

Towbin, H., T. Staehelin, and J. Gordon. 1979. Electrophoretic transfer of proteins from polyacrylamide gels to nitrocellulose sheets: procedure and some applications. Proc. Natl. Acad. Sci. USA 76:4350-4354.

van Egmond, M., C. A. Damen, A. B. van Spriel, G. Vidarsson, E. van Garderen, and J. G. van de Winkel. 2001. IgA and the IgA Fc receptor. Trends Immunol. 22:205-211.

van Zaane, D., and J. Ijzerman. 1984. Monoclonal antibodies against bovine immunoglobulins and their use in isotype-specific ELISAs for rotavirus antibody. J. Immunol. Methods 72:427-441.

Watson, D. L. 1976. The effect of cytophilic $\mathrm{IgG}_{2}$ on phagocytosis by ovine polymorphonuclear leucocytes. Immunology 31:159-165.

Watson, D. L., and A. K. Lascelles. 1973. Mechanisms of transfer on immunoglobulins into mammary secretion of ewes. Aust. J. Exp. Biol. Med. Sci. 51:247-254.

Weisbart, R. H., A. Kacena, A. Schuh, and D. W. Golde. 1988. GMCSF induces human neutrophil IgA-mediated phagocytosis by an IgA Fc receptor activation mechanism. Nature 332:647-648.

Williams, M. R., and A. W. Hill. 1982. A role for IgM in the in vitro opsonisation of Staphylococcus aureus and Escherichia coli by bovine polymorphonuclear leucocytes. Res. Vet. Sci. 33:47-53.

Wilson, I. D. 1972. Studies on the opsonic activity of human secretory IgA using an in vitro phagocytosis system. J. Immunol. 108:726-730.

Zhang, G., J. R. Young, C. A. Tregaskes, P. Sopp, and C. J. Howard. 1995. Identification of a novel class of mammalian Fc gamma receptor. J. Immunol. 155:1534-1541.

Zipursky, A., E. J. Brown, and J. Bienenstock. 1973. Lack of opsonization potential of $11 \mathrm{~S}$ human secretory A. Proc. Soc. Exp. Biol. Med. 142:181-184. 